PUBLIK: Jurnal Manajemen Sumber Daya Manusia, Administrasi dan Pelayanan Publik

Sekolah Tinggi Ilmu Administrasi Bina Taruna Gorontalo

Volume VI Nomor 1 Juni 2019

\title{
STRATEGI PEMASARAN PRODUK TABUNGAN BOHUSAMI PADA PT. BANK SULUTGO CABANG GORONTALO
}

\author{
Yahya Antu', Moh. Noval Dukalang ${ }^{2}$ Amrain Mustafa ${ }^{3}$ \\ STIA Bina Taruna Gorontalo \\ yogapraditya771@yahoo.co.id
}

\begin{abstract}
ABSTRAK
Tujuan Penelitian ini adalah untuk untuk mengetahui Strategi pemasaran produk tabungan Bohusami di Bank PT. Bank SulutGo cabang Gorontalo. Penelitian ini menggunakan jenis deskriptif pendekatan kualitatif. Pengumpulan data dilakukan melalui observasi dan wawancara menggunakan pedoman wawancara yang di ajukan kepada sejumlah informan. Teknik analisa data menggunakan teknik analisis SWOT (strength, weakness, opportunity, threat).

Hasil penelitian berdasarkan fokus penelitian diatas dapat disimpulkan bahwa: Strategi pemasaran yang dilakukan oleh bank SulutGo cabang Gorontalo untuk memasarkan produk tabungan Bohusami belum sepenuhnya efektif dijalankan dan belum dilakukan secara optimal dan terukur dalam meningkatkan jumlah nasabah. Kualitas sumber daya manusia yang dimiliki masih kurang pada bagian marketing dan belum paham tentang strategi-strategi marketing yang baik untuk produk tabungan Bohusami. Sarana dan prasarana yang dimiliki oleh bank sulutGo dalam memfasilitasi kegiatan pemasaran belum memadai sehingga kegiatan pemasaran belum optimal dilakukan. Persaingan Produk tabungan yang sejenis sehingga menimbulkan kecenderungan penurunan market share tabungan. Promo-promo yang dilakukan oleh bank sulutGo untuk produk tabungan Bohusami kurang kreatif dan kurang meningkatkan minat masyarakat untuk menabung.

Disarankan kepada bank SulutGo cabang Gorontalo Meningkatkan SDM pemasaran, meningkatkan fasilitas penunjang kegiatan pemasaran, menambah fitur-fitur menarik produk tabungan Bohusami. Meningkatkan kreatifitas kegiatan promosi yang sudah dilakukan agar produk lebih dapat bersaing dengan produk kompetitor.
\end{abstract}

Kata Kunci: Strategi Pemasaran, Produk Tabungan

\section{PENDAHULUAN}

Arus globalisasi dan digitalisasi tengah melanda sendi-sendi kehidupan manusia padaumumnya dan dunia usaha pada khususnya. Hal tersebut disebabkan oleh perkembangan teknologi yang semakin canggih yang mampu memperkecil berbagai macam hambatan, baik yang datangnya dari alam maupun hambatan budaya, guna menuju suatu tatanan dunia baru yang tanpa batas. Perkembangan ini terasa juga dalam dunia usaha di Indonesia, hal ini ditandai dengan banyaknya 
PUBLIK: Jurnal Manajemen Sumber Daya Manusia, Administrasi dan Pelayanan Publik Sekolah Tinggi Ilmu Administrasi Bina Taruna Gorontalo Volume VI Nomor 1 Juni 2019

perusahaan-perusahaan

bermunculan, baik yang bergerak di bidang keuangan perbankan, industri maupun perusahaan jasa, yang menyebabkan kompetisi antara perusahaan tersebut semakin tajam, sehingga menuntut para manajer untuk tampil lebih profesional dalam mengelola usaha pemasaran untuk menjamin bahwa perusahaan yang bersangkutan beroperasisecara efektif dan efisien.

Dalam usaha mencapai kesuksesan perusahaan, peranan manajer dalammemilih dan merencanakan strategi pemasaran sangat penting dalammemenuhi kebutuhan konsumen. Akan tetapi, dengan mengembangkan strategi pemasaran, manajer harus mempertimbangkan untuk tidak hanya memenuhi kebutuhan konsumen saja, melainkan juga posisi industri perusahaan yang bersangkutan dibanding pesaing. Oleh karena itu, manajer pemasaran harusmerancang strategi pemasaran yang kompetitif yang sepadan dengan posisi dansumber daya pesaing dan secara terus menerus menyesuaikan strategistrategitersebut dengan persaingan yang terus berubah.

Peta persaingan perbankan di Indonesia semakin ketat, terlebih dengan masuknya bank-bank asing ke Indonesia serta sejumlah akuisisi bank asing terhadap bank lokal. Serbuan bank asing tersebut khususnya dari negara-negara di Asia Tenggara mengarah pada terwujudnya
Masyarakat Ekonomi ASEAN (ASEAN Economic Community) pada tahun 2015 untuk sektor non keuangan dan sektor keuangan pada tahun 2020. Hal itu memberikan imbas pada pangsa aset bank milik asing (bank swasta milik asing, bank campuran, dan unit bank asing) yang hanya $11 \%$ pada 1998 telah tumbuh pesat menjadi $34 \%$ pada 2011 dan menurunnya pangsa pasar bank nasional dari $89 \%$ menjadi tinggal $66 \%$. Persaingan yang ketat ini harus dihadapi dengan strategi yang tepat, sehingga di masa mendatang perbankan lokal tidak menjadi penonton di negeri sendiri.

Lembaga keuangan perbankan dalam kinerja untuk kesuksesan baik manajemen maupun operasionalnya, lembaga bank harus memiliki beberapa konsep dasar yang menyertainya di dalam lalu lintas pelayanan diantaranya adalah strategi pemasaran bank. Pemasaran bukan berarti hanya terpaku pada kegiatan promosi dan penjualan saja. Namun lebih dari itu. Dalam dunia perbankan, yang dimaksud dengan konsep strategi pemasaran adalah upaya untuk mencapai kepuasan nasabah terhadap penggunaan produk yang dikeluarkan oleh pihak bank, entah itu penggunaan produk berupa tabungan, giro, deposito maupun service (jasa pelayanan) yang diberikan pada nasabah.

Pencapaian yang berupaya pada tingkat kepuasan nasabah dikaitkan dengan berbagai cara ataupun strategi yang dijalankan oleh pihak lembaga 
PUBLIK: Jurnal Manajemen Sumber Daya Manusia, Administrasi dan Pelayanan Publik Sekolah Tinggi Ilmu Administrasi Bina Taruna Gorontalo Volume VI Nomor 1 Juni 2019

keuangan perbankan. Diantara berupa strategi produk (tabungan, giro dan deposito), strategi lokasi (layout), strategi harga suatu produk dan jasa service, strategi promosi untuk penjualan dengan tingkat maximal seduce. Banyaknya profit yang didapatkan oleh suatu bank sangat tergantung pada bagaimana suatu upaya pemasaran itu sendiri dapat berjalan lancar. Untuk itu, maka diperlukan beberapa konsep dan strategi yang matang guna untuk menilai kinerja manajemen dan operasional dari perbankan itu sendiri.

PT. Bank SulutGo cabang Gorontalo adalah salah satu bank pembangunan daerah yang sebagian besar saham kepemilikannya dimiliki oleh pemerintah daerah dalam hal ini seluruh pemerintahan provinsi, kabupaten/kotase-sulawesi utara dan pemerintah provinsi, kabupaten/kota seprovinsi Gorontalo sejak tahun 2015. Fungsinya sebagai perusahaan perbankan untuk memajukan wilayah propinsi sulawesi utara dan Gorontalo dalam hal ekonomi dan infrastruktur serta pembangunan kualitas sumber daya manusia pada umumnya. Produk yang dihasilkan oleh PT. Bank SulutGo antara lain Simpeda, tabungan Bunaken, Tabunganku, rekening Giro, Deposito, tabungan Bohusami, tabungan PNS, tabungan SIMPEL.

Saat ini jumlah nasabah di Bank SulutGo cabang Gorontalo adalah sejumlah 15.317 nasabah dengan rinciannya adalah tabungan umum 336 nasabah, tabungan PNS 6.366 nasabah, tabungan pendiun 838 nasabah, tabunganKu $\quad 3.140 \quad$ nasabah,
TabunganKu BSM 36 Nasabah, Tabungan Bunaken 40 nasabah, Tabungan Bohusami 839 nasabah, tabungan simple 337 nasabah, dan tabungan Simpeda 3061 Nasabah.

Salah satu produk tabungan unggulan dari bank SulutGo adalah tabungan Bohusami dimana produk ini diharapkan mampu menarik minat masyarakat. Tabungan Bohusami adalah Produk khusus bagi nasabah Perorangan kelas menengah kebawah, sebagai wujud apresiasi kepada masyarakat Sulawesi Utara dan Gorontalo untuk lebih menarik minat masyarakat menjadi nasabah Bank SulutGo.

Dari total jumlah nasabah 839 merupakan nasabah sejak tahun 2011 sampai tahun 2018. Namun sejak 3 tahun terakhir jumlah nasabah tabungan bohusami mengalami penurunan. sejak tahun 2015 jumlah nasabah hanya mengalami kenaikan sebesar $0,72 \%$ setiap tahunnya.

Pada umumnya masyarakat tahu bahwa bank SulutGo merupakan banknya bagi pegawai negeri sipil (PNS). Ini terindikasi dari jumlah nasabah yang ada di bank SulutGo cabang Gorontalo terbanyak adalah pegawai negeri sipil. Hal Ini bisa dimaklumi karena gaji pegawai negeri sipil di pemerintahan provinsi, pemerintahan kabupaten/kota melalui bank SulutGo.

Begitupun dengan rekening yang ada di bank SulutGo cabang Gorontalo banyak sekali rekening nasabah yang pasif (dormant) yang meningkat di setiap tahunnya. Rekening pasif 
PUBLIK: Jurnal Manajemen Sumber Daya Manusia, Administrasi dan Pelayanan Publik Sekolah Tinggi Ilmu Administrasi Bina Taruna Gorontalo Volume VI Nomor 1 Juni 2019

(dormant) adalah rekening yang tidak melakukan transaksi selama enam bulan berturut-turut baik untuk transaksi debit ataukredit, dan bila sudah melampaui jangka yang sudah ditentukan yakni enambulan, maka rekening tersebut akan terblokir secara otomatis. Kebanyakan nasabah membiarkan rekening mereka pasif karena sudah memiliki rekening di bank lain atau merasa bahwa rekening tersebut sudah tidakmenguntungkan. Selain itu ketidaktahuan nasabah mengenai keutungan dan kemudahan fasilitas yang dapat diperoleh ketika menggunakan produk dari bank SulutGo tersebut juga sangat berpengaruh pada loyalitas nasabah.

Strategi pemasaran wajib dilakukan oleh pihak bank SulutGo cabang Gorontalo apabila ingin memenangkan persaingan dengan bank-bank lain yang ada di provonsi Gorontalo. Persaingan antara Bank SulutGO dan perbankan lainnya yang ada di provinsi Gorontalo baik Bank Swasta (seperti Bank BCA, Bank Panin Bank Mega,dll) maupun Bank BUMN (seperti Bank BNI, Bank Mandiri, BRI, BTN) semakin ketat karena inovasi produk tabungannya juga mempengaruhi nasabah untukloyal menggunakan produk tabungan dari bank-bank tersebut. Bank SulutGo harus memliki strategi yang menarik untuk mendapatkan nasabah yang sebanyak-banyaknyadan meminimalkan rekening pasif.

Untuk mengimbangi aktivitas masyarakat yang semakin tinggi, BankSulutGo terus berupaya mengembangkan dan mengenalkan produk-produknya termasuk produk tabungan Bohusami. Strategi ini dilakukanagar produk tabungan Bohusami diharapkan mampu memberikan solusi dalam meringankan aktivitas nasabahnya dengan memberikan fasilitas dan manfaatuntuk memenuhi kebutuhan dan keinginan nasabahnya, serta dapat bersaing dengan kompetitor yang mengeluarkan produk sejenis dan diharapkan dapat meminimalkan rekening dormant.

Semakin meningkatnya persaingan perbankan dalam kategori produk yang sama, perusahaan tidak dapat membuat jasa sesuai dengan keinginan perusahaan, tetapi harus sesuai dengan kebutuhan, keinginan dan harapan nasabah. Dalam menciptakan keunggulan bersaing, maka pemahaman terhadap kebutuhan dan keinginan pelanggan serta penilaian terhadap kinerja dan harapan pelanggan, pengembangan strategi pemasaranbank SulutGo cabang Gorontalo diharapkan dapat meningkatkan jumlah nasabah.

Selama ini strategi pemasaran yang dilakukan oleh PT. Bank Sulut Go cabang Gorontalo belum maksimal dilakukan karena beberapa permasalahan antara lain jumlah pegawai bagian pemasaran hanya berjumlah 1 orang pegawai. Di bank sulutGo cabang Gorontalo penempatan karyawan pada bagian marketing hanya 1 orang dalam melakukan perumusan strategi baik perencanaan, targetting, promosi dan kegiatan marketing lainnya. Tidak ada bagian 
PUBLIK: Jurnal Manajemen Sumber Daya Manusia, Administrasi dan Pelayanan Publik Sekolah Tinggi Ilmu Administrasi Bina Taruna Gorontalo Volume VI Nomor 1 Juni 2019

atau unit yang melakukan kegiatan pemasaran secara terpadu.

Permasalahan lainnya adalah sarana dan prasarana yang ada belum memadai dalam mengakomodasi kegiatan pemasaran. Jumlah kenderaan dalam melakukan kegiatan marketing hanya 1 unit mobil untuk menjangkau seluruh wilayah Gorontalo. selain itu bank sulutGo belum memiliki ruangan yang representatif dalam melakukan kegiatan marketing. Permasalahan berikutnya adalah persaingan produk tabungan sejenis dari bank-bank lainnya. Persaingan produk yang sama tidak dapat dihindari dikarenakan setiap perusahaan ingin memasimalkan setiap peluang yang ada dalam meningkatkan jumlah nasabah. Terutama dari bank-bank yang secara financial memiliki keuangan yang mapan dan image perusahaan atau brand yang kuat dimata masyarakat dalam memilih bank sebagai tempat menyimpan uang.

Selain itu pihak bank sulutGo kurang kreatif dalam melakukan promosi untuk mengenalkan produk tabungan Bohusami kepada masyarakat. Promosi yang dilakukan oleh bank SulutGo cabang Gorontalo dalam memasarkan produk tabungan Bohusami hanya sebatas membagikan brosur kepada masyarakat yang datang di kantor cabang serta membagikan brosur di sekolah-sekolah.

Strategi pemasaran pada dasarnya adalah rencana yang menyeluruh, terpadu, dan menyatu dibidang pemasaran, yang memberikan panduan tentang kegiatan yang akan dijalankan untuk dapat tercapainya tujuan pemasaran.Setiap perusahaan dalam memasarkan produk yang dihasilkan menjalankan strategi pemasaran, sehingga dapat mencapai sasaran yang diharapkan. Salah satu dari strategi pemasaran yang sering dilakukan oleh suatu perusahaan adalah dengan cara melakukan penyebaran pemasaran itu sendiri. Suatu produk tidak akan dibeli bahkan dikenal apabila konsumen atau masyarakat tidak mengetahui kegunaanya, keunggulanya, dimana produk diperoleh, dan berapa harganya. Untuk itulah perusahaan harus memiliki strategi untuk menarik nasabah atau masyarakat untuk menggunakan produk tabungan Bohusami.

Yang paling utama adalah bagaimana manajemen PT. Bank SulutGo cabang Gorontalo terus melakukan upaya memberikan kepuasan bahkan mempertahankan nasabahnya dengan berbagai upaya karena persaingan yang semakin ketat antara perbankan dan berakibat berpindahnya nasabah ke bank-bank lain, yang lebih menguntungkan dan pelayanan yang memuaskan.

\section{PERMASALAHAN}

Berdasarkan latar belakang
masalah di atas, maka rumusan
masalah dalam penelitian ini yaitu
bagaimanakah strategi pemasaran
produk tabungan Bohusami pada PT.
Bank SulutGo cabang Gorontalo?


PUBLIK: Jurnal Manajemen Sumber Daya Manusia, Administrasi dan Pelayanan Publik Sekolah Tinggi Ilmu Administrasi Bina Taruna Gorontalo Volume VI Nomor 1 Juni 2019

\section{TUJUAN DAN MANFAAT PENELITIAN}

Adapun yang menjadi tujuan dari penelitian ini adalah untuk mengetahui strategi pemasaran produk tabungan Bohusami pada PT. Bank SulutGo cabang Gorontalo dalam meningkatkan jumlah nasabah.

\section{Manfaat Penelitian}

Manfaat yang diharapkan dari pelaksanaan penelitian ini terdiri dari manfaat teoritis dan manfaat praktis.

Manfaat teoritis

Manfaat teoritis sebagai sarana pengembangan ilmu pengetahuan khususnya bidang Administrasi Bisnis di dalam pengembangan ilmu pengetahuan serta dapat dijadikan sebagai bahan acuan bagi penelitian berikutnya.

Manfaat Praktis

Sebagai bahan masukan bagi pihak perusahaan dalam rangka memperbaiki Strategi pemasaran produk tabungan yang dilakukan oleh perusahaan kepada masyarakat. Memberikan sebuah konstribusi di bidang pemasaran produk tabungan di perusahaan perbankan melalui marketing strategic yang baik.

\section{METODE PENELITIAN}

Penelitian ini bertujuan untuk mengetahui dan memperoleh gambaran tentang strategi pemasaran produk tabungan di PT. Bank SulutGo cabang Gorontalo. Jenis penelitian adalah deskriptif pendekatan kualitatif yang bermaksud untuk memahami fenomena tentang apa yang dialami oleh subjek penelitian misalnya perilaku, persepsi, motivasi, tindakan dan lain-lain. Secara holistik dan dengan cara deskripsi dalam bentuk kata-kata dan bahasa, pada suatu konteks khusus yang alamiah dan dengan memanfaatkan berbagai metode ilmiah (Moleong, 2007:6)

\section{Fokus Penelitian}

Penelitian ini difokuskan pada:

\section{Sumber Daya Manusia (SDM)}

SDM yaitu kualitas dan kuantitas pegawai di bagian pemasaran dalam melakukan strategi pemasaran untuk meningkatkan jumlah nasabah.

\section{Sarana Prasarana}

Sarana prasarana yaitu akomodasi dan transportasi untuk melakukan kegiatan pemasaran.

\section{Persaingan Produk Tabungan}

Persaingan produk tabungan yaitu jenis produk yang dipasarkan dan jenis layanan yang diberikan kepada calon nasabah dengan produk tabungan yang sejenis dengan bank lain.

\section{Kreatifitas Promosi}

Kreatifitas promosi yaitu bentukbentuk promosi atas produk-produk tabungan yang dilakukan dalam menarik minat nasabah.

\section{HASIL PENELITIAN DAN PEMBAHASAN}

Berdasarkan deskripsi hasil penelitian di atas maka bahasan hasil wawancara difokuskan pada Strategi Pemasaran Produk Tabungan Bohusami yakni sebagai berikut:

Sumber Daya Manusia 
PUBLIK: Jurnal Manajemen Sumber Daya Manusia, Administrasi dan Pelayanan Publik Sekolah Tinggi Ilmu Administrasi Bina Taruna Gorontalo Volume VI Nomor 1 Juni 2019

Jumlah karyawan pada PT. Bank SulutGo cabang Gorontalo sebanyak 50 orang. Pada umumnya latar belakang pendidikan karyawannya adalah S1 dengan rata-rata lama bekerja dari seluruh karyawan adalah 2 tahun. Untuk bagian marketing produk tabungan bohusami pada bank SulutGo cabang Gorontalo hanya 1 orang karyawan. seluruh pegawai PT. Bank SulutGo cabang Gorontalo adalah bagian marketing atau pemasaran. Tidak ada pegawai khusus yang ditunjuk untuk menjadi karyawan yang melakukan kegiatan pemasaran produk tabungan Bohusami. Semua karyawan akan turun melakukan kegiatan pemasaran bila sewaktu-waktu diharuskan turun melakukan kegiatan pemasaran produk tabungan. Kegiatan pemasaran yang dilakukan oleh bagian marketing hanya sebatas perencanaan marketing dan harus menyesuaikan jadwal kerja unit kerja lainnya apabila akan melakukan kegiatan pemasaran produk tabungan Bohusami.

Berdasarkan bahasan tersebut menunjukkan bahwa karyawan pada bagian marketing. pemasaran produk tabungan Bohusami belum efektif dikarenakan pegawai yang turun melakukan kegiatan pemasaran tidak memiliki keahlian khsusus bidang marketing produk tabungan.informasi tentang produk tabungan yang disampaikan oleh karyawan pada nasabah tentang produk tabungan Bohusami belum sepenuhnya dipahami oleh nasabah dikarenakan kualitas sdm yang dimiliki karyawan dalam kegiatan pemasaran belum sesuai yang diharapkan.
Sarana dan Prasarana

Dalam penunjang kegiatan PT. Bank SulutGo cabang Gorontalo seharusnya memiliki berbagai sarana dan prasarana agar masyarakat atau nasabah tertarik untuk menabung.

Berdasarkan penelitian dan hasil wawancara menunjukkan bahwa PT. Bank SulutGo cabang Gorontalo belum memiliki sarana prasarana yang memadai dalam melakukan kegiatan pemasaran. Pengaturan tata letak ruangan serta peralatan penunjang kegiatan yang tidak sepenuhnya berfungsi mengakibatkan tidak maksimalnya kegiatan yang dilakukan oleh bagian marketing. Anggaran yang dimiliki masih terbatas sehingga perluasan bangunan serta pengadaan barang penunjang belum terealisasi.

PT. Bank SulutGo cabang Gorontalo belum memenuhi kegiatan pemasaran produk tabungan Bohusami dengan prasarana yang memadai seperti filling cabinet, rak tempat brosur dan buletin serta AC yang rusak serta beberapa peralatan penunjang lainnya yang tidak berfungsi dengan baik.

Selain fasilitas gedung dan prasarana penunjang lainnya, kegiatan pemasaran memerlukan sarana mobil sebagai penunjang kegiatan pemasaran di lapangan. Dalam hal ini PT. Bank sulutGo cabang Gorontalo hanya memiliki 1 unit mobil sebagai penunjang kegiatan pemasaran dan pemakainnya bergantian dengan unit kerja lainnya.

Persaingan produk tabungan

Produk tabungan Bohusami Bank SulutGo dalam meningkatkan jumlah nasabah harus memiliki strategi 
PUBLIK: Jurnal Manajemen Sumber Daya Manusia, Administrasi dan Pelayanan Publik Sekolah Tinggi Ilmu Administrasi Bina Taruna Gorontalo Volume VI Nomor 1 Juni 2019

inovasi agar dapat bersaing dengan berbagai bank-bank sejenis yang berada di Gorontalo.

Berdasarkan hasil penelitian dan wawancara menunjukkan bahwa PT. Bank SulutGo cabang Gorontalo kesulitan dalam meningkatkan jumlah nasabah, karena belum memiliki inovasi strategi dalam meningkatkan jumlah nasabah produk tabungan Bohusami untuk dapat bersaing dengan produk-produk tabungan yang sejenis dari bank-bank.

Kreatifitas Promosi

Kegiatan promosi produk tabungan Bohusami dilakukan melalui Goes to School, ke pesantrenpesantren modern, ke pasar, ke kantorkantor pemerintahan daerah Kabupaten/kota Gorontalo, ke UMKM dan industri kecil, dan ke perguruan tinggi serta melakukan presentasi dengan mengundang calon nasabah untuk mempromosikan produk Tabungan Bohusami yang sudah melalui pembidikan terlebih dahulu. Selain itu, secara khusus personal selling dilakukan oleh petugas Customer Service (CS).

Berdasarkan hasil penelitian dan wawancara menunjukkan bahwa PT Bank SulutGo Cabang Gorontalo dalam mempromosikan produk tabungan Bohusami kegiatan promosi yang dilakukan dengan membagi brosur kepada calon nasabah di sekolah-sekolah, di kantor-kantor swasta dan pemerintah tanpa adanya inovasi ataupun terobosan baru dalam melakukan promosi. promosi yang dilakukan oleh bank sulutGo cabang Gorontalo untuk produk tabungan
Bohusami adalah melalui periklanan, promosi penjualan, dan publisitas. Hanya saja promosi yang dilakukan masih terbatas pada orang-orang tertentu saja dan hanya orang-orang yang tahu saja dengan kegiatan perbankan.

\section{SIMPULAN}

Berdasarkan deskripsi hasil penelitian dan pembahasan tersebut maka dapat disimpulkan sebagai berikut:

1. Strategi pemasaran yang dilakukan oleh bank SulutGo cabang Gorontalo untuk memasarkan produk tabungan Bohusami belum sepenuhnya efektif dijalankan dan belum dilakukan secara optimal dan terukur dalam meningkatkan jumlah nasabah.

2. Kualitas sumber daya manusia yang dimiliki masih kurang pada bagian marketing dan belum paham tentang strategi-strategi marketing yang baik untuk produk tabungan Bohusami.

3. Sarana dan prasarana yang dimiliki oleh bank sulutGo dalam memfasilitasi kegiatan pemasaran belum memadai sehingga kegiatan pemasaran belum optimal dilakukan.

4. Persaingan Produk tabungan yang sejenis sehingga menimbulkan kecenderungan penurunan market share tabungan.

5. Promo-promo yang dilakukan oleh bank sulutGo untuk produk tabungan Bohusami kurang kreatif 
PUBLIK: Jurnal Manajemen Sumber Daya Manusia, Administrasi dan Pelayanan Publik Sekolah Tinggi Ilmu Administrasi Bina Taruna Gorontalo Volume VI Nomor 1 Juni 2019

dan kurang meningkatkan minat masyarakat untuk menabung.

\section{SARAN}

Berdasarkan kesimpulan tersebut, maka disarankan hal-hal sebagai berikut:

1. Untuk lebih mengefektifkan dan mengoptimalkan kegiatan pemasaran agar produk tabungan Bohusami lebih dikenal luas oleh seluruh lapisan masyarakat Gorontalo.

2. Meningkatkan SDM pemasaran khususnya dalam produk pendanaan, memberikan pelatihan dan keterampilan marketing, serta proses rekrutmen yang kompeten serta melaksanakan program evaluasi dan perbaikan untuk terus mengembangkan potensi SDM yang menjadi pendukung untuk mewujudkan tujuan perusahaan di masa mendatang.

3. Meningkatkan fasilitas penunjang kegiatan pemasaran baik berupa sarana mobil, motor, dan prasarana berupa gedung dan ruangan yang refresentatif, serta kualitas internet yang memadai.

4. Menambah fitur-fitur menarik produk tabungan Bohusami agar dapat memenangkan persaingan untuk produk sejenis dari bankbank lainnya.

5. Meningkatkan kreatifitas kegiatan promosi yang sudah dilakukan agar produk lebih dapat bersaing dengan produk kompetitor. Promosi juga perlu didukung dengan anggaran untuk mendukung kegiatan tersebut.

\section{DAFTAR PUSTAKA}

Adi dan Purwanto. 2006. Analisis Pengaruh Implementasi Relationship MarketingDi Sebuah Penyedia Jasa Internet Di KaranganyarPada KepuasanPelanggan, Loyalitas Pelanggan dan Kualitas Pelayanan. FokusManajerial, Vol 4, No 1, hal 14-22.

Adrian. Hartono. 2012. Pengaruh Display, Kepercayaan Merek, KeakrabanMerek, Persepsi, Harga Terhadap Intensi Pembelian dan Pembelian TakTerencana. Jurnal Ekonomika Bisnis Universitas Kristen Satya Wacana, dan 1 (1), $1-22$.

Alma, Buchari. 2009. Manajemen Pemasan dan Pemasaran Jasa. Edisi Revisi. Bandung: Alfabeta

Assauri, Sofjan. 2013. Manajemen Pemasaran. Jakarta : Rajawali Pers.

Bungin, Burhan. 2007. Penelitian Kualitatif; Komunikasi, Ekonomi, KebijakanPublik, dan Ilmu Sosial Lainnya. Jakarta: Kencana Prenada Media Group.

David, Fred R. 2010. Strategic Management: A Competitive Advantage Approach, Concepts and Cases (13th Edition). Prentice Hall International, London. 
PUBLIK: Jurnal Manajemen Sumber Daya Manusia, Administrasi dan Pelayanan Publik Sekolah Tinggi Ilmu Administrasi Bina Taruna Gorontalo Volume VI Nomor 1 Juni 2019

Daft, Richard L. 2007. Manajemen Edisi 1, Alih bahasa oleh Edward Tanujaya dan Shirly Tiolina. Salemba Empat, Jakarta,

Dr. Sudaryono. 2016. Manajemen Pemasaran: Teori dan Implementasi. Banten:Penerbit Andi.

Hasibuan, Malayu S.P. 2009. Manajemen: Dasar, Pengertian, dan Masalah Edisi Revisi. Jakarta: Bumi Aksara.

Ita Oktavianti. 2016. Analisis Strategi Pemasaran Produk Tabungan BSM PT. Bank Syariah Mandiri, KCP Lebak-Bante. Penelitian ilmiah.

John A. Pearce II dan Richard B.Robinson, Jr. 2008. Manajemen Strategis Formulasi, Implementasi dan Pengendalian. Jakarta: Salemba Empat.

Jogiyanto Hartono. 2013. "Teori Portofolio dan Analisis Investasi”, Edisi Kedelapan. Yogyakarta: BPFE.

Kasmir. 2010. Pengantar Manajemen Keuangan. Jakarta: Kencana Prenada Media Group.

$\begin{array}{llr}2011 . & \text { Analisis } & \text { Laporan } \\ \text { Keuangan: } & \text { Jakarta: } & \text { PT } \\ \text { RajaGrafindo Persada. } & \end{array}$

Kotler, dan Keller. 2012. Manajemen Pemasaran. Edisi 12. Jakarta: Erlangga

Kuncoro, Murdrajat. 2006. "Ekonomi Pembangunan". Jakarta: Salemba Empat.
Manullang. 2012. Dasar-Dasar Manajemen. Yogyakarta: Gadjah Mada University Press.

Moleong, Lexy J. 2007 Metodologi Penelitian Kualitatif. Bandung: PT. Remaja Rosdakarya Offset,

Mudlofir, Rita Andini dan Agus Supriyanto. 2016. Pengaruh ROA, ROE, EPS, Inflasi, DER dan Inventory Turnover. Universitas Pandanaran Semarang.

Musa,Hubeis dan Najib,Mukhamad. 2008. Manajemen Strategis Dalam Pengembangan Daya Saing Organisasi. Jakarta: PT. Elex MediaKomputindo.

Poerwanto. 2006. New Business Administration. Yogyakarta: Pustaka Pelajar.

Pearce II, John A. dan Robinson Richard B. Jr. 2008. Manajemen Strategis 10. Jakarta: Salemba Empat.

Rangkuti, Freddy. 2008. The Power of Brands, Cetakan Ketiga, Jakarta; Gramedia Pustaka Utama.

Safroni, Ladzi. 2012. Manajemen dan Reformasi Pelayanan Publik dalam

Konteks Birokrasi Indonesia. Surabaya: Aditya Media Publishing.

Silalahi, Ulber. 2009. Metode Penelitian Sosial. Bandung: PT. Refika Aditama.

Veithzal Rivai. 2013. Manajemen Sumber Daya Manusia Untuk 
Perusahaan Dari Teori Ke Praktek. Bandung: Rajagrafindo persada.

W. Rintatik, Sudarno. 2008. "Kewirausahaan 3". Solo: PT. Tiga Serangkai Pustaka Mandiri.

\section{Sumber lain:}

Undang-Undang RI no. 10 Tahun 1998, 1998, “Tentang Perubahan UU No. 7 Tahun 1992 Tentang Perbankan”, Jakarta : CV. Eko Jaya.

Bank Indonesia. 1998. UU No.10 tahun 1998, Tentang Perubahan Terhadap UU No. 7 tahun 1992, Jakarta 